\title{
Governance, democracy and accountability from a network governance perspective within the city of Ekurhuleni
}

\begin{tabular}{|c|c|}
\hline \multicolumn{2}{|c|}{$\begin{array}{l}\text { Authors: } \\
\text { Jerome J. Patience }{ }^{1} \text { (1) } \\
\text { Danielle Nel }{ }^{1} \text { (]) }\end{array}$} \\
\hline \multicolumn{2}{|c|}{$\begin{array}{l}\text { Affiliations: } \\
\text { 'School of Public } \\
\text { Management, Governance } \\
\text { and Public Policy, College of } \\
\text { Business and Economics, } \\
\text { University of Johannesburg, } \\
\text { Johannesburg, South Africa }\end{array}$} \\
\hline \multicolumn{2}{|c|}{$\begin{array}{l}\text { Corresponding author: } \\
\text { Jerome Patience, } \\
\text { Jerome.patience@gmail.com }\end{array}$} \\
\hline \multicolumn{2}{|c|}{$\begin{array}{l}\text { Dates: } \\
\text { Received: } 09 \text { Apr. } 2021 \\
\text { Accepted: } 07 \text { Oct. } 2021 \\
\text { Published: } 28 \text { Feb. } 2022\end{array}$} \\
\hline \multicolumn{2}{|c|}{$\begin{array}{l}\text { How to cite this article: } \\
\text { Patience, J.J. \& Nel, D., 2022, } \\
\text { 'Governance, democracy and } \\
\text { accountability from a } \\
\text { network governance } \\
\text { perspective within the city of } \\
\text { Ekurhuleni', Africa's Public } \\
\text { Service Delivery and } \\
\text { Performance Review 10(1), } \\
\text { a554. https://doi. } \\
\text { org/10.4102/apsdpr. } \\
\text { v10i1.554 }\end{array}$} \\
\hline \multicolumn{2}{|c|}{$\begin{array}{l}\text { Copyright: } \\
\text { ( } 2022 \text {. The Authors. } \\
\text { Licensee: AOSIS. This wo } \\
\text { is licensed under the } \\
\text { Creative Commons } \\
\text { Attribution License. }\end{array}$} \\
\hline \multicolumn{2}{|l|}{ Read online: } \\
\hline 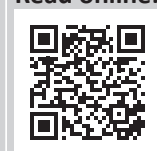 & $\begin{array}{l}\text { Scan this QR } \\
\text { code with your } \\
\text { smart phone or } \\
\text { mobile device } \\
\text { to read online. }\end{array}$ \\
\hline
\end{tabular}

Background: Local government as the sphere of government that directly impacts the lives of communities must create a milieu of interacting with communities in terms of planning, execution and the monitoring and evaluation of the success or failure of its programmes. Local government has a moral and a legislative duty to involve communities thereby extending and deepening democratic and accountable government processes.

Aim: This study aimed to analyse how democratic and accountable governance can assist in creating sustainable processes of involvement of its communities. Local government is government's main contributor to the socio-economic growth and development, not only of a country but more so, its people. The article emphasises improvement in the current processes of community involvement in strategic planning and the execution of such plans in general and at the city of Ekurhuleni (COE) in particular, situated in the Gauteng province of South Africa. It further aims to indicate to the city that its processes are not taking into account communities' feelings of self-worth, humanity and identity.

Methods: The study followed a qualitative approach in terms of the interpretative phenomenological analysis (IPA) and the network governance theory served as the theoretical framework.

Results: The findings indicate that communities and community bodies who are to serve as actors in collaboration with the city in their planning and execution processes experience alienation from council, councillors and even ward committees and their members. Community actors are of the opinion that councillors only know them during their election campaigns, and when elections have come and gone, councillors are gone as well.

Conclusion: Recommendations include that when dealing with community affairs there should be no political party affiliation and that councillors must know that communication is a two-way tool that should benefit all parties. Councillors are to commit themselves to the improvement of community members' lives and socio-economic upliftment.

Keywords: public participation; democracy; accountability; governance; interpretative phenomenological analysis; feelings; identity; humanity; service delivery.

\section{Introduction}

Local government has to contribute to the improvement of people's lives and it is that sphere of government where policies become by-laws. These by-laws directly affect citizens' dignity and sense of worth as beneficiaries of government's programmes. The National Development Plan (NDP) states that stronger municipalities form part of the wider goals of its plans for a better South Africa (National Planning Commission [NPC] 2011:363). Municipalities have been playing a vital developmental role in the execution of their strategic plans in the Integrated Development Plan (IDP). During the past few years, there has been an upsurge in the number of service delivery protests and many political commentators are of the opinion that on average there are 13 protests a day; however, most of these are peaceful (Flanagan 2016:4). According to the Municipal IQ report of 2016, Gauteng experienced 26\% of the total number of protests in South Africa during January to April 2016. The South African Local Government Information Centre (SALGIC) is of the opinion that service delivery protests are occurring mostly in informal settlements and underdeveloped areas, because they remain a challenge for government in terms of effective service delivery (SALGIC 2018:39). The cause of these protests is mainly that communities feel let 
down and isolated by their elected officials. A member of the African National Congress Youth League (ANCYL), said that there have been no improvements in his area of Johannesburg South for some time, and that the area has been developed through protests because it is the only way that government listens to them (Chernick 2016:4). During his mayoral election campaign, the former mayor of the city of Johannesburg indicated that 'active citizenry is the only way to bring change as citizens are entitled to challenge laws, rules and existing structures within the democratic process' (Mashaba 2016:5).

This study aims to indicate whether the city of Ekurhuleni (COE) meets the local government objective to provide democratic and accountable government for its communities. Councillors within the COE need to gain the trust and confidence of community members and they should collaborate with communities in resolving long-standing issues of mistrust, service delivery incapacity, financial misconduct and other forms of malpractices within the municipality. However, these are not stand-alone issues and this collaboration with communities can contribute to greater openness, accountability and honesty by both councillors and municipal officials. According to King IV report (Institute of Directors South Africa [IODSA] 2016:35), the aim of local government is to improve governance, democracy and accountability. Therefore, network governance theory will serve as the lens for the researcher and as this study's theoretical framework. Actors of network governance theory include municipal officials, councillors, members of ward committees, the business community and religious community. As a qualitative enquiry, this study followed an interpretative phenomenological analysis (IPA) where an inductive process guides the data collection, analysis and interpretation stages. The researcher based his enquiry on an interview protocol consisting of at least 12 questions that relate to governance, democracy and accountability within the COE. The rich information that was gathered formed the basis of this study's primary data and the researcher was able to conduct 20 semi-structured interviews with a homogenous group of individuals, couples and groups representing their communities.

\section{Democracy, governance, accountability and network governance}

Democracy by its very nature is inclusive and societies are to thrive on their participation in democratic processes. Obayori (2009) in Gberevbie (2014:134) stated that '[all] democracies in modern time must be participatory' and this requires popular participation of all people, not only in national elections but also in those issues affecting their daily lives. Aristotle was the first person to formulate and use the word 'democracy' within the local government context; his premise was that citizens are to participate in their local authorities' affairs (Masango 2001:41). The former public protector, Ms Madonsela, said that citizens are to define, deepen and enrich democracy in a manner that meets their needs and improves their lives (Madonsela 2017:n.p). The democratisation of service delivery increases the chances of offering citizens' justifications for the power structures to which they are beholden and it is all about allowing them to participate in decisions regarding the services that government institutions are delivering (Bratu 2010:303). The aim of service delivery should be to improve the lives of the recipients of such services and government plays a crucial role in the financing, regulation and overseeing the effectiveness with which it delivers such services.

Governance as an outflow of democracy has generated interesting debates over the last few years. Many scholars use governance and good governance in conjunction with words such as rule of law, accountability, transparency, development-oriented leadership, freedom of expression and association, and responsiveness (Alkali 2004; Babawale 2007; and Kim et al. 2005 in Gberevbie 2014:137), Torfling \& Sørensen 2014:333; Bernhardt 2016:15). Municipal governance plays a vital role in that communities are to be involved in municipal planning not only in the annual budget but more so in the development of the IDP, which is the strategic planning document of the municipality. The basis of this relationship is trust between the municipality and its communities where communities can negotiate the outcomes and the results with its social, political and economic actors (South African Cities Network [SACN] 2016:203).

The key instruments of good institutional local governance are the IDP and budget, risk management, internal control, performance review and management, compliance with statutory and regulatory framework, in-year monitoring and reporting, annual planning and reporting, effective internal auditing, effective audit committees, effective municipal public accounts committees and effective political and administrative leadership (Patience 2015:53). The effective running of these municipal processes forms the basis of accountability and it denotes effectiveness. Accountability goes beyond holding leaders accountable through elections as it boils down to how effective the administrative machinery of government is. This is because the elected leaders are directly using the administration to achieve their public purpose.

The White Paper on local government of 1998 stated local government must '[work] with citizens and groups within the community to find sustainable ways to meet their social, economic and material needs and improve the quality of their lives'. Schermbrucker (2020:1) said that the failure of municipalities to work within communities is widespread, longstanding and systematic (I think he meant systemic). Schermbrucker (2020:2) further stated that '[if] communities understand the budgets and resources available and are involved in planning, the potential for conflict over the allocation of resources is drastically reduced'. 
Network governance is also known as third party, joint-up, collaborative, partnering, holistic, multi-level or cogovernance between structures of government and other agencies in order to render specific services (Auriacombe \& Van der Waldt 2016:94). Kooiman (1993), Mayntz (1993a, 1993b), Scharpf (1994) and Klijn (2008) in Torfling and Sørensen (2014:333) equate governance with network forms of governance that view it as either a hybrid of hierarchy and market or as a differentiating mode of governing supplementing hierarchies and markets. Because government has to deal with ever increasing complicated problems, it has discovered that it does not have all the means and answers to solve societal problems. It therefore has to rely more and more on other social and economic actors to allow these innovators to come up with creative responses. This government model requires executives to organise resources that in many instances belong to others in order to co-produce public value and to concentrate on managing people and programmes for longer (Auriacombe \& Van der Waldt 2016:94). Government cannot solve complex horizontal problems with vertical solutions; therefore, its role has changed from direct service provider to generator of public value (Goldsmith 2008:2).

This means that political decision-making is no longer the exclusive domain of formal government structures, but that governance as a process of public policy formulation and implementation now takes place by means of different formal and informal institutions, mechanisms and processes (Sørensen \& Torfling 2004:2).

Implicit to network governance is the fact that network actors are all dependent on each other and they have to coordinate their institutional arrangements, activities and their perceptions regarding both the challenge at hand and the intended solutions (Klijn \& Koppenjan 2016:2).

According to Klijn and Koppenjan (2016:4), characteristics of network governance include actor interdependencies, resulting in a high degree of strategic complexities and there are high unpredictable courses of (inter)actions because the actions of one actor influences the interests and strategies of others. Other characteristic includes actors that are autonomous; their interactions are complex as each one has his or her own perceptions of problems, solutions and strategies, however, and over time, network interactions show durability (Klijn \& Koppenjan 2016:4). Benefits of network governance are speed, flexibility, increased reach, choice, enhanced quality and effectiveness, specialisation in that new skills and talents that actors bring with them allow for innovation of government's traditional systems, no unnecessary increase in cost for government, replacing political accountability with accountability by constituents to constituents (Goldsmith 2008:13; Wilikilagi 2009:11). The disadvantages of network governance are: inadequate protection of public values, chances that those most in need might be excluded, incorrect quality measures, choice and competition can give way to private monopolisation, possible loss or lack of necessary government oversight, goal congruence, fragmented coordination and accountability (Goldsmith 2008:14; Wilikilagi 2009:11). The concepts of democracy, governance, accountability and network governance form the basis of this study because if the city can address and improve on these, citizens will at least feel that they have a responsive, democratic and accountable local government.

\section{Contextual variables of participation in local government in South Africa}

Participation by social, political and economic actors in local government matters form the basis of effective local governance. The laws, regulations, guidelines and policies that guide governance, democracy and accountability in the South African local government context are the following: the Constitution of the Republic of South Africa, Act no. 108 of 1996 (hereafter referred to as the Constitution); the White Paper on Transforming Public Service Delivery (Batho Pele, People First) of 1997; the White Paper on Local Government of 1998; the Municipal Structures Act (MStA), Act no. 117 of 1998; the Municipal Systems Act (MSA), Act no. 32 of 2000; the Municipal Finance Management Act, Act no. 56 of 2003 (MFMA); and the Municipal Property Rates Act, Act no. 6 of 2004 (MPRA).

Section 152 of the Constitution states that local government must provide communities with democratic and accountable government. The Batho Pele principles of consultation, service standards, access, courtesy, openness and transparency, redress and value for money, all aim to improve the efficiency and effectiveness in the way government provides services at all spheres (Batho Pele 1997:1). These principles aim to provide recipients of services with legitimate rights to demand the rendering of quality services from their municipalities.

Chapter Four of the MStA requires a municipality to establish ward committees with the objective to enhance participatory democracy in local government. Chapter Four of the MSA states that community members have a right to submit complaints to the municipality or its political structures through the mechanisms provided and that the municipality or its political structures must provide responses to their complaints. Further to this, section 16 (1) of the MSA requires a municipality to develop a culture of municipal governance, thereby invoking democratic municipal processes in order for communities to hold their council and councillors accountable. Chapter Five of the MSA requires municipalities to draw up an IDP, which forms the strategic plan of the municipality. Section 35 of the MSA provides direction to the IDP process and describes that the IDP as '[The] principal strategic planning instrument which guides and informs all planning and development and all decisions with regard to planning, management and development in the municipality'.

Section 4 of the MPRA requires municipalities to follow a community participation process in adopting a rates policy and that they must make all tariffs and other financial 
documents available on their websites in terms of section 21B of the MSA. A municipality must also provide mechanisms and create conditions for communities to participate in the IDP process, establish, implement and review its performance management system, and allow them to participate in budgetary processes. Other mechanisms of participation include: building the capacity of local communities to enable effective participation, fostering a culture of community participation by both councillors and employees of a municipality, decision-making on the provision of municipal services and drafting of municipal by-laws.

Public participation is an open, fair and accountable process through which individuals and groups within a community are encouraged to exchange their views and influence decision-making (Overstrand Municipality 2016:3). Creighton (2005:7) stated that even though there are many definitions of public participation, most decisions include elements such as administrative decisions. Public participation is an organised process involving the public and it requires that participants are to have some level of impact or influence on the final decisions. Public participation, also referred to as community or citizen participation, strengthens democracy, legitimises democratic institutions, empowers citizens to participate and make decisions, creates ownership of policies and programmes, shares information on matters of collective importance, educates citizens and sustains the democratic culture (Masango 2001:37). This article prefers the use of public participation above the other usages of interaction with actors. According to the Overstrand Municipality (2016:8), the principles which are to form part of all public participation processes include: inclusivity, diversity, the building of public participation capacity, transparency, flexibility, accessibility, accountability, trust, commitment, respect and integration.

One process that really needs the involvement of communities and where they can make an impact is the budget process. This is because section 15 of the MFMA states that a municipality may, except where otherwise provided in the act only incur expenditure in terms of an approved budget; and within the limits of the amounts appropriated for the different votes in an approved budget. Patience (2015:82) stated that the budget as planning and communication tool can lead to the refinement of the municipality's short-term plans and that it communicates policy. However, this is only possible if community actors know and understand council objectives and that these objectives are the results of collaboration between all parties. Participatory budgeting (PB) is only one form of participatory processes and it can be defined as a form of participatory democracy whereby citizens and civil society organisations (CSOs) have equal rights to participate directly in determining fiscal policy. The aim of PB should never be to exclude any group of community actors; in fact, it should bring greater numbers of actors and collaborators into the fold of collaboration. Ebdon (2000) in Razaki and Lindberg (2012:778) stated that PB is highly dependent on the culture and structure of the municipality, and it may not be a panacea for a particular municipality if it is not able to consider the inputs of the broader public.

\section{Research design and methodology}

The aim of this qualitative, interpretative phenomenological study is to determine whether the COE applies the conceptual and theoretical underpinnings of democracy and accountable government, and also, whether communities feel that the city is making a difference to their lives. According to Creswell (2014:255), qualitative research takes place in participants' natural settings where the bases of assumptions are different from quantitative design and theory and in which hypotheses are not a priori. Creswell's (2014:255) view of qualitative research focused on participants' perceptions and experiences, and the way they make sense of their lives.

\section{Interpretative phenomenology}

According to Stewart and Mickunas (1974), cited in Waugh and Waugh (2004:406), phenomenology as a derivative from the Greek words 'phainomenon' means appearance and 'logos' means to reason or word, and can be loosely translated as 'reasoned enquiry'. Phenomenologists, as critics of positivism, argue that research methods of the physical sciences are not well suited for the study of human behaviour and society. These critics insisted that in order to understand human behaviour, one must recognise that the manner in which one perceives the world affects how such one reacts to it and that perceptions differ because reality is a social construct (Reiners 2012:1). Another variant of phenomenology as developed by Martin Heidegger (1889-1976) was interpretive phenomenology whereby he extended hermeneutics as a philosophy of interpretation (Reiners 2012:1). Shinebourne (2011:17) stated, '[IPA] draws on three theoretical approaches namely phenomenology, hermeneutics and idiography to inform its distinctive epistemological framework and research methodology'.

Hermeneutics, translated from Greek, means 'to interpret' or 'to make clear', or to comprehend a person's mind-set and language by which such one experiences the world (Pietkiewicz \& Smith 2012:362). Therefore, language is the medium that shares or communicates meaning. For Heidegger, it is impossible to put aside our experiences (bracketing) related to a phenomenon under study because personal awareness is so intrinsic to phenomenological research (Laverty 2003:24; Pietkiewicz \& Smith 2012:362; Smith, Flowers \& Larkin 2009:25). Being interested in interpreting and describing human experience, Heidegger believed that bracketing is not necessary because hermeneutics presumes prior understanding (Reiners 2012:2). According to Van Manen (1990), cited in Alase (2017:10), hermeneutic phenomenology is the 'lived experiences' of research participants (phenomenology) and the interpretation (text) of the life they have lived and experienced (hermeneutics).

Idiography refers to the commitment to the single case in its own right, or to a process that moves from the examination of 
the single case to more general claims (Smith et al. 2009:29). Interpretative Phenomenological Analysis of idiographic theory requires that every participant's experience of the phenomenon is to be interpreted and recognised, not only explained or explored like in the case of a thematic analysis approach. Idiography as a theoretical underpinning of IPA aims for an in-depth focus of the particular and commitment to a detailed finely-textured analysis, something that is not possible in nomothetic research studies which focus on aggregated data (Shinebourne 2011:22; Smith et al. 2009:30).

This study uses IPA because the researcher does not want to bracket his biases such as his experience, training and knowledge. The reason for this is that the researcher has over 20 years of experience in municipal finance, having worked in both revenue and expenditure divisions and currently working in the budget office of the COE. Thus, the researcher uses his experience and knowledge to the advantage of the study in the field of Public Management and Governance and its subfield of Municipal Finance and Public Budgeting. By applying IPA, this study will be useful because the researcher regards it as complex and something unique to be undertaken. Many studies regarding PB, democratic and accountable government and their variables have been undertaken. However, these were not conducted on a microlevel where participants can influence the timeframes of the IDP, budgeting and other democratic processes at municipal level. The IPA involves asking critical and in most instances difficult questions, and these are the types of questions the researcher hopes to get answers to, all with the aim of improving municipal service delivery to the people and thereby improving people's lives.

\section{Method \\ Participants}

The selection of 20 participants for this study was based on purposive and snowball sampling that are examples of nonprobability sampling, in order to reach a homogenous group of specifically poor community members who can participate in this study and contribute to its research objectives. The IPA studies have small sample sizes that could be a limitation, but Smith et al. (2009:51) argued that a reduced sample size allows for richer depth of analysis, something that a larger sample could inhibit. A richer, deeper and more interpretative analysis could be viewed as drawing the researcher away from the original meaning, but Smith et al. (2009:51) encouraged researchers to go beyond what is immediately apparent in the content. Purposive sampling is a dominant strategy for IPA because it looks for people who are able to provide in-depth information within specific categories such as age, culture, experiences and it is not random but purposeful (Smith et al. 2009:56).

\section{Data collection and analysis}

The IPA concentrates on participants' lived experiences of reality, how they see themselves in relation to the world they are living in. Therefore, the interpretivist approach encourages researchers to examine the non-verbal communication closely during interviews. Analysing qualitative data using the IPA framework is an inspiring activity; however, the major drawbacks of it is its complexity and the amount of time it takes. Data analysis in terms of IPA is unique in the sense that it typically involves an in-depth analysis of a set of case studies, and that the results of the analysis do not stand on its own but it is rather discussed in relation to extant literature within the discipline (Smith 2004:43). The semi-structured interviews with the participants formed the primary source of data collection and it required from the researcher to be actively present and he or she has to take notice of non-verbal cues displayed by a participant because both the participant and researcher are busy with knowledge creation.

Meaning is central to IPA and the aim is to uncover the content, context and complexity of those meanings rather than just measuring its frequency. The researcher engaged in an interpretative relationship with the participant in terms of the transcript, therefore the read and reread thereof. It is difficult and near impossible to do IPA research without an audio recorder, as the researcher would have missed the gist of the interview and thereby losing important nuances thereof. Without a recorder, the researcher would have to listen and jot down what the participant is saying, therefore he might not have been of assistance to the participant when needed and the interview could have run into possible difficulty because of his divided attention. These distractions would have hampered the researcher's ability to concentrate on the finer non-verbal cues that might at time have said much more than the spoken word. However, the researcher obtained approval from the participants and the reasons for using the audio recorder were clarified to them prior to the interview.

The duration of the interview is generally a minimum of one hour and the researcher was always mindful of the fact that interviews can differ from one to the next and that voice recordings are to be made in order to be able to transcribe the conversation in verbatim (Pietkiewicz \& Smith 2012:366). The average time of an interview was 50 minutes per participant and the researcher discovered that where interviews were longer it was because of the frustration of the participants in most instances but also the level of knowledge participants have regarding their service delivery expectations and the failure thereof

\section{Data analysis and the hermeneutic circle}

Iterative analysis or the process of sustained engagement is moving back and forth through a range of different ways of thinking about the data rather than completing one-step after the other (Smith et al. 2009:28). Iterative analysis assists the researcher to build a relationship with the data and meaning, and it shifts constantly and can happen at a number of different levels. All these different meanings relate to each other because they offer varied perspectives on parts or the whole and the coherence of the text as concluded by Smith et al. 
(2009:28). The researcher applied the seven-step data analysis guide as proposed by Smith et al. (2009:82). These steps required from the researcher to read each transcript several times in which preliminary summaries and connecting comments are recorded. This is followed by further rereading whereby preliminary themes have been identified and the researcher constantly compared these themes and where necessary modifications were made in order to reach a hierarchical structure. From these, interlinkages of superordinate themes and subordinate themes were developed, and this hierarchical flow of information allowed the researcher to lay the basis of the study in terms of on which superordinate themes to concentrate. This procedure has to be followed for every transcript where individual themes were adjusted and coherently ordered by going back and forth between transcripts thereby ensuring emergence of themes that really belong within the set of data. The final step involves taking these interpretations to deeper levels of analysis by employing metaphors and temporal referents and the importation of other theories (in this case network governance theory) to be used as a lens through which analysis can be effected.

\section{Validity and rigour}

Qualitative research has always been criticised for its lack of providing rigorous or objective results. However, this is a flawed criticism because unlike positivism, interpretivism produces 'natural' subjective data that are not open to test rigour objectively (MacDermott 2002:266).

Yardley (2000), cited in Smith et al. (2009:180), proposed four broad principles for assessing quality which the researcher tried to apply as best as possible to the research in order to make the study truly valid and to achieve as much rigour as possible. These principles as applied by the researcher include:

- sensitivity to context,

- commitment and rigour,

- transparency and coherence, and

- impact and importance.

During the entire process, the researcher showed sensitivity to the socio-cultural setting of the study, by reading up and becoming aware of existing literature on the topic and the material obtained from the participants (Smith et al. 2009:180). Sensitivity included the researcher's appreciation of the interactional nature of data collection within the interview situation. By showing empathy, putting the participant at ease, recognising interactional difficulties, and negotiating the intricate power play where the researcher as expert meets the experiential expert, the participant.

The researcher showed commitment by the degree of attentiveness he gave to the participants during the interview and the meticulous care that was given to the process of data analysis (Smith et al. 2009:181). Rigour refers to the thoroughness with which the study is undertaken, and as Smith etal. (2009:181) indicated, it refers to the appropriateness of the sample to be tested, the quality of the interview and the completeness of the analysis that is undertaken.

In terms of the third principle of transparency and coherence, the researcher lucidly indicated the stages of the research process in his descriptions of the study's write-ups (Smith et al. 2009:180). Coherence refers to how logically everything ties into each other. According to Yardley, cited in Smith et al. (2009:182), there will be contradictions as these often form the richest part of the texts; however, the researcher ensured that the analysis of the contradictions in itself was not contradictory.

In terms of impact and importance as principles, Yardley, cited in Smith et al. (2009:182), made the important point that it doesn't matter how well a research has been conducted, its test of validity lies in the extent to which it is able to convey to the reader something 'interesting, important and useful'. The researcher aimed, to the best of his ability, to have made the project 'interesting, important and useful' to the benefit of human beings and science.

\section{Ethical considerations}

This article followed all ethical standards for research without direct contact with human or animal subjects.

\section{Results}

The analysis of the 20 interviews resulted in one superordinate theme and three subordinate themes indicating communities' frustrations in terms of the municipal services they receive from the city. The provision of democratic and accountable government is the superordinate theme as it applies to the data that the researcher obtained from the interviews. As an objective of local government, the provision of a democratic and accountable government as superordinate theme received the highest number of references (Patience 2021:284). The other objectives include the promotion of social and economic development, ensure provision of sustainable services, encourage involvement of communities and community organisations in local government matters and promotion of a safe and healthy environment, however, these do not form part of this study.

\section{The role of councillors, ward committee members and especially senior municipal officials in the promotion of democratic and accountable government}

The task of language is to convey information and to describe reality in general. Therefore, the researcher specifically concentrated on participants' use of language. The researcher referenced the contexts of participants' concerns and tried to identify the usage of abstract concepts whereby he could help to make sense of the patterns of their meaning. Table 1 indicates participants' feedback in the role of councillors, ward committee members and senior municipal officials in terms of the promotion of democratic and accountable government.

The Participant H (female, retiree) and Participant N (female, small business owner, mid 30's) capture the duties of 
TABLE 1: The role of councillors, ward committee members and especially senior municipal officials in the promotion of democratic and accountable government. Feedback Participant Feedback

Councillors are not available, councillors fear their communities and there is a gap between councillors and communities, communication between $\mathrm{A}$ and $\mathrm{E}$

councillor and his or her community is a two-way street.

Councillors are to be part of the budget steering committee, councillors are to be honest.

G

Councillors are forever absent, councillors are not sticking to their promises, and our councillor does nothing, absolutely nothing. $\mathrm{H}$ and $\mathrm{R}$

Engage communities more, timeous sharing of information, conduct regular public meetings at least quarterly, if councillors want to improve municipal services they must get involved with the community and be a beacon of hope for the hopeless.

We are like a forgotten people as councillors only know us when it is election time, we have feelings of anger, hurt and betrayal, these are 'ingredients of a bomb', councillors must do their work because the people had enough and are fed up.

Ward committee members have been fairly elected, use all forms of social media to inform communities about the budget preparations, community $\mathrm{D}$, E, G, K and U2 involvement is to be an on-going process during the year, listen and involve communities, information sharing is very important, government should be proactive and listen to the people before assets are destroyed, ward committee members are to understand municipal governance issues.

Non-involvement of councillors and ward committee members in community affairs is a reason for service delivery protests, make communities proud of their involvement of municipal projects, inform communities of their civic responsibilities and duties.

Officials are to perform their duties and not be the cause of conflict between councillors and communities, officials' attitude is bad and off-putting. Officials are to be responsive to communities' needs and direct the public to the right offices and officials who can be of assistance.

L

Poor municipal services do not make residents proud of $\mathrm{COE}$, treat people with courtesy and respect, communities must know who to escalate their $\mathrm{M}$ problems to and officials should respond to the needs of the public, attitudes of officials towards communities are to be improved.

COE, city of Ekurhuleni.

councillors succinctly. Participant $\mathrm{H}$ responded as follows to the question of: Do you feel that there is regular contact between your community and your councillor? How often would you like this contact to take place?

'While the water was spilling like that, I called the ward councillor and told him to come to my place. I told him how long the water spilling was going on and that the officials insisted me to pay the account, I will come ma'am, I will come, but he never came right until today he never came. That is the ward councillor, whatever happens, he is never to be found. Why do we still have to vote for this XXX party? This ward councillor is involved with nothing because it is the first thing you hear people ask: what does this councillor do for us? Nothing, why do we have to vote for him. When there is such a crisis, especially electricity, especially electricity, then he must call a meeting and tell us: this is the situation at hand. I buy R100 of electricity per month but I am more without electricity than with electricity and is he concerned about that, and if we protest then he has the police sitting there at his house protecting him, and what about us? You see that is the thing!'

Participant N (female, small business owner, mid 30's) responded with the following on the question of: How do you feel during these protests; do you think government or the municipality listens to your pleas? What other avenues are there for you to get their attention?

'What I said to you earlier, when you get a person to a point where they are angry, they are hurt, they feel betrayed, and I think worse of all, they feel betrayed by their own, you are actually giving them ingredients for a "bomb." These things are not done because people feel that they want to destroy municipal property, we are so illiterate, we are so unthankful, its frustration, frustration, people are frustrated. This country has sold its soul, you know, at the expense of the electorate. The people who are voting for them, are the very people who are today made to suffer, people are protesting for what? Are they not protesting for electricity, is it not right to protest for that?'

\section{What communities have to do for the promotion of democratic and accountable government to succeed?}

Table 2 provides feedback from the participants regarding their role as community members in the promotion of democratic and accountable government.
TABLE 2: What communities have to do for the promotion of democratic and accountable government to succeed?

\begin{tabular}{ll}
\hline Feedback & $\begin{array}{l}\text { Participant } \\
\text { Feedback }\end{array}$ \\
\hline $\begin{array}{l}\text { Ward committee members only involve certain people and as a } \\
\text { community we feel vulnerable, scared and unsafe during protests, } \\
\text { government does not listen therefore the protests, no respect is given } \\
\text { by government to the people. }\end{array}$ & $\mathrm{C}, \mathrm{J}, \mathrm{N}$ and Q \\
$\begin{array}{l}\text { The municipality must be driven by what is important for the community, } \\
\text { the budget is not an accurate reflection of communities' needs. }\end{array}$ & \\
$\begin{array}{l}\text { Use people's skills in the community to their own benefit, greed is a } \\
\text { factor in ward politics. }\end{array}$ & E and J \\
$\begin{array}{l}\text { Inform communities about municipal projects when they start and } \\
\text { finish, involving communities will benefit businesspeople, young } \\
\text { people and labourers, inform communities of the limitations the } \\
\text { municipality has with the budget, people will prioritise themselves by } \\
\text { coming to an agreement which projects should be undertaken and } \\
\text { which must be allowed to stand over until the following financial year. }\end{array}$ & \\
\hline
\end{tabular}

Participant M (female, mid 40's) responded the following to the question of: What suggestions in terms of processes would you give to the municipality in order for them to get your stamp of approval in terms of service delivery, if any?

'Communicate the truth to communities, and involve them and tell them that we cannot produce this or the other thing, because last year we were supposed to, we were short of money, etc. and people will understand when you tell them the truth. We can tell them these are the impediments, which is why we could not do this or that. Officials are to tell the truth and this starts by doing small things.'

Participant N (female, small business owner, mid 30's) responded as follows to the question of: What suggestions in terms of processes would you give to the municipality in order for them to get your stamp of approval in terms of service delivery, if any?

'If government gives us a way forward, more especially through education, skills in construction maybe like that, we cannot depend on government for everything, we will have to pull up our socks, and we as the community we want to pull up our own socks, please Ekurhuleni keep your promises you made to us. If they want our vote, they come with this, then we follow-up on their promises, after that we put them there on top, they forget about us. That is a very important thing that they should know is that we, the people have put them there. They should never forget about us and always involve us, do not think that you are too high now, but next time you want to come back and want us to vote for you again.' 


\section{How community actors are to involve themselves in the Integrated Development Plan, budgeting and other interactive municipal processes?}

Community actors and their involvement in municipal processes form the basis of the following subordinate theme. Table 3 indicates the feedback as received from community actors and their involvement in the municipal processes.

Participant B's (male, community worker, mid 60's) response to the question of: Do you and your community participate in the annual budget public participation process? What should the municipality do to get you involved?

\begin{abstract}
'You know what, there again, I do participate. Government says for instance, the IDP is within 3 weeks' time, they know exactly the dates and the locality, where is this participation. Two days before the event, they sending flyers out, putting up posters, stating there will be an IDP meeting in town, and there will be buses. There again, lack of information from their side, they do not prepare the people in advance so that they can give them copies of what the budget is, for them to be prepared when they get there and know what they should request, they don't, they don't. And in actual fact, the IDP, it is your needs, the community's needs that you put into the IDP so that that can be collated and then taken further. For me to get people involved is information, information and participation from government's side, not on a once off or two days before, and there should be a continuity plan after that. They do not come back saying that a project has been stopped because of $\mathrm{X}, \mathrm{Y}$ or $\mathrm{Z}$, there again, lack of information.'
\end{abstract}

Municipal services form the tangible and measurable elements by which communities measure their council's seriousness to the promotion of democratic and accountable government.

The following discussion will be in terms of how the participants understand their lived experiences of municipal services, their role in democratic and accountable government for the researcher to provide an account of their 'engagement in the world' as proposed by Larkin and Thomas (2011:112).

\section{Discussion of findings}

This discussion focuses on the emergent themes in detail whereby the researcher will enter into deeper analysis by interpreting the superordinate and the subordinate themes. Triangulation of themes will now take place with extant literature and theory in order to propose recommendations to the council and the municipal administration. These recommendations include ways as to how the city can improve municipal service delivery and thereby improve communities' experiences in their undertakings with the COE. Network governance theory was the lens through which the analysis was undertaken and the unanticipated outcomes of themes prompted the researcher to consult additional literature in order to address the findings of these additional developments. Successful IPA research requires from researchers that their interpretations be rooted in the meeting of researcher and the text (interpretation). Pietkiewicz and Smith (2012:369) are of the view that the basis of the researcher's interpretative and theoretical account is the narratives of participants' text of their experiences in their own words.

This subordinate theme indicates the distrust and animosity that exist between councillors and their constituents. Many of the research participants do not know their councillors and in instances where they know them, they indicated that there is little to no contact with them at all. Councillors do not make themselves available to communities, as they should. Therefore, when the IDP and budgeting processes take place and they have to interact with their communities, they become scared (Esau 2007:18). During these public meetings, communities display great animosity and anger towards their political leadership. Even when community members are struggling with their accounts or have complaints and the administration takes too long to resolve these, they feel that their councillors are not there to assist them. Communication between the councillor and community members is a two-way communication tool that can work to the benefit of both the councillor and his or her constituents (Smith \& Visser 2009:60). No political agenda should be pushed when it comes to community affairs. However, this is easier said than done because councillors are deployed by their political masters who want them to push their political party's agenda. In addition, this is the reason for the gap that exists between the councillor and community members for in a number of cases, the ward committee and the community do not subscribe to the politics of the councillor or vice versa.

TABLE 3: How community actors are to involve themselves in the integrated development plan, budgeting and other interactive municipal processes. Feedback

No interaction with councillor, political agendas are being pushed, proper planning of public participation meetings, prepare people in advance for meetings, give information to equip them for these meetings, councillors are weak in terms of participation or interaction with their communities therefore there is no budget for their community, processes and execution of plans are imperative, council reports are to be handed not only to councillors but also to ward committee members, keep control over contractors, new projects are to flow from previous year's budget to ensure continuity, plan the IDP and budgeting process in smaller groups, only combine meetings later, rather take longer and ensure better responses and greater credibility of the process.

Community consensus is all important, the councillor has to speak to all members of the community not only certain sections of the community, people are not welcoming of others who also want to participate, build houses for the people then we can see there is improvement.

Seniors in the community are also to be included and informed, fetch us for the community meetings as you do when it is elections, conduct meetings during the entire year as people cannot remember what was decided on last year, the new budget should flow from the previous one, budget has already been decided on somewhere and the municipality just wants the community to legitimise it.

Communities want to be involved before the IDP and budget meetings take place because they want to come to meetings prepared, take our inputs into $\mathrm{K}$ and $\mathrm{M}$ the budgeting process.

Information sharing is vital, councillors and ward committee members are to be capacitated, councillors are the link between communities and council and they are to be involved with the determination of budget priorities, not only members of the mayoral council (MMCs), direct democracy through strong civic movements.

IDP, Integrated Development Plan.

Participant Feedback
B, M and $R$
C
I, M and $R$
K and $M$
L and $M$

Participant Feedback 
The participants to the study indicated that if councillors want to have their commitment they first have to engage them more rigorously, information is to be shared timeously, regular public meetings are to be conducted at least quarterly. There are those who suggested that they want monthly meetings and that these can be chaired by the ward committee members. Councillors are to be the beacon of hope of their constituents and both ward and proportional representative (PR) councillors are to be involved in the IDP and budgeting process (Piper \& Deacon 2008:3; Smith \& Visser 2009:60). Currently, the PR councillor does not have any input into the IDP and budgeting process. It is not even required from PR councillors to attend these public meetings.

People are filled with feelings of anger, hurt and betrayal because they feel that they are not being taken serious by the municipality's IDP, budgeting and most other municipal processes; these are all 'ingredients of a bomb' (Patience 2021:282). So often, these bombs explode when the municipality or the political leadership expect it the least, and this is an indication that the people are now sick and tired and that they have had enough.

Ward committees should teach communities their civic responsibilities and duties. However, the same committees are also to teach councillors and council their duties and responsibilities and indicate to both parties how they ought to work together to create harmonious relationships in terms of service delivery (Esau 2007:15). Information should be freely available and getting the community involved in municipal processes should always be done for the right reasons and to their benefit. Ward committees should never be partisan and it must strive to serve the interest of everyone in the community, and therefore their actions are to be transparent (Piper \& Deacon 2008:4; Smith \& Visser 2009:60).

Ward committees' main function is to influence the public participation process by identifying and prioritising their developmental needs (Esau 2007:13; Sebugwawo 2016:1). The objective of development is to bring about a purposeful change to the environment both quantitatively and qualitatively by which the well-being of people can be improved. Shaidi et al. (2011:164) proposed that the ward committee system be compulsory instead of being a voluntary option for municipalities. One participant stated that the question currently is: 'isn't government expecting too much from people who are being paid a stipend in terms of what they have to deliver for the municipality?' Many ward committee members are using their positions as a stepping-stone for their own political advancement and enrichment. However, Smith and Visser (2009:60) were of the view that ward committees are to play an integral role in the municipal IDP process and that they are to act as communication channel between communities and council, and vice versa.
Officials are to be responsive to the needs of communities (Patience 2021:297) and so often they themselves stay in these communities. Therefore, one can ask the question: Why does the councillor, ward committee member or even officials not see that there is a pothole for the last week, month or year? The Batho Pele principles require that public officials treat people with respect and in terms of section 195 of the Constitution. Section 195 lays down the basic values that are to inform all actions in public administration. Communities must be educated as to their rights and responsibilities as it is important for them to know who to inform of their problems and when they can expect their issues to be addressed (Patience 2021:356).

Communities have to involve themselves in the running of the municipality by holding their elected officials accountable. This can only take place where communities are allowed to involve themselves and where councillors and ward committee members share information with everyone and not with a few. By holding council and councillors accountable for their actions, communities will be able to influence the budgeting process and the strategic planning processes (IDP) will reflect communities' needs (Diedericks \& Seitlholo 2018:11; Esau 2009:7). These needs will be reflective of all members across the entire spectrum of children, youth, middle aged and even the aged because facilities are to be made available to and for all in the community.

Communities should be proud of who they are and what council has already provided in terms of infrastructure because they have given the inputs for those structures to be provided in the first place (Diedericks \& Seitlholo 2018:10). They therefore have to encourage their fellow community members not to destroy municipal infrastructure and where these things are happening, the perpetrators are to be made aware that they will not get away with it because entire communities are suffering when a clinic or a library has been torched. Those members in the community who are capacitated in terms of qualifications or experience can also assist ward committees and the councillor to provide education and skills training for the rest of the community. This will assist communities to become self-reliant in terms of civic education as the people will know what questions they are to ask elected officials and for them to know where to take their complaints to instead of always holding destructive service delivery protests.

Network actors can be any group of people who can influence the policies of council and who are impacted by council's policies. Actors play an important role in bringing council and councillors to the discussion table (Sørensen \& Torfling 2004:4). This requires that all councillors should make themselves available to interact with whichever actor without bias. During these interactions, no political agendas are to be pushed because most members of communities are only interested in things that are working and that it must work to their benefit. Actors can assist in getting communities prepared for their IDP, budgeting and other municipal 
interactions thereby increasing accountability. This will also require the municipality to make information available beforehand for these actors to interrogate the information as received. Actors will also be able to check what was on the previous year's budget and can then prepare communities to ask questions as to why a project was not completed on time, if not, why not, and what has happened to such funds? Community members will also be able to check against the annual financial statements (AFS) and performance reports whether set municipal targets have been reached. Where council has taken a decision to appoint a service provider based on the proposal by the councillor or the ward committee, the actors together with the councillor and ward committee members will know what the tender specifications were for the service provider to follow. It will not only be a few people who have decided as to who will be getting a tender from the municipality. From the first day, the service provider starts with the project he or she will know that the community as a stakeholder will keep him or her accountable for the final delivery of the project.

When knowing that things are transparent, councillors, ward committee members will be alert and conscious about the possible questions that could be asked of them, and that they cannot hide information from communities (Diedericks \& Seitlholo 2018:13). This will encourage both councillors and ward committee members to conduct their monthly and quarterly meetings.

This will ensure that by the time when the annual IDP and budget meeting takes place ample time can be spent on budget-related issues instead of service delivery issues. Network actors are to assist communities and councillors to hold contractors accountable because many members of the community are unemployed, and they can see which of these contractors are not doing their work, as they ought to (Sørensen \& Torfling 2004:18). Actors will ensure that financial matters are transparent for the community to ensure that contractors do not receive payments if they did not deliver a service. This is possible because these network actors will receive their monthly ward reports from the municipality indicating such payments. In addition, all actions undertaken by councillors and ward committee members are to be honest and above reproach, and they ought to have involved the communities in their decision-making.

Monthly reports on infrastructure development will indicate what has been paid for per ward and what was supposed to have been delivered by service providers. Variance reports are to be tabled at meetings with communities whereby councillors and ward committees can interrogate the actions of the municipality for them to see how payments are made to suppliers and how a project is flowing in terms of its deliverables.

Where necessary, communities are to be trained by actors as to what these reports contain and how to interpret it in order for them to ask the right questions from their councillors and ward committee members (Diedericks \& Seitlholo 2018:13). Councillors, as the link between council and communities are to ensure that direct democracy takes place and that through these strong civic movements are encouraged thereby improving themselves and their communities.

Government is currently experiencing a trust and confidence deficit and the performance of local government in South Africa is often questioned against alleged financial irregularities, maladministration, corruption, and mismanagement (Kroukamp 2016:106). This is evident in many service delivery protests that are flaring up repeatedly, and in the allegations that are levelled against councillors and in many instances against senior municipal officials. Confidence in government institutions is vital in achieving stability and development as it attracts cooperation of citizens to the agreed policies and programmes of government (Esau 2007:11). Confidence encourages people to work with government as they would have noticed that the institution is being run efficiently and effectively. Even though it is difficult to measure government's overall efficiency, direct democracy in itself can influence the level of municipal resources and the public goods that can be derived from it. People want to be associated with institutions that work and deliver on their mandates, and there is research that indicates that under the right institutional arrangements of direct decision-making mechanisms, voters will involve themselves and thus governance becomes more inclusive, and consequently, there is improvement in economic outputs (Asatryan \& De Witte 2015:66). Restoring confidence is an on-going process, especially in our current state in which people want greater accountability from government.

\section{Conclusions and recommendations}

The provision of democratic and accountable government starts with both councillors and ward committee members realising that their main task is to fulfil their constitutional mandate by rendering quality and effective services to communities. The COE can start by educating its councillors to be responsive and to act on people's needs whenever communities and other actors confront them. The office of the Speaker has to implement strategies whereby communities are able to hold their councillors and the political parties they represent accountable. In order to hold political parties accountable, a proposal is therefore to move the Participation Unit that currently resorts under the office of the Speaker to the office of the city manager in order to be politically unbiased in its interactions with communities. However, a political party wants to escape accountability; therefore, they will never give their electorate or opposition any such fodder to be used against them. All senior managers must get the necessary training in the field of Public Management for them to know what is happening in communities for them to feel, breathe, see and experience reality as communities are experiencing it. Development of humanity must become the mantra in public management and governance in order to improve the lives of people. The aim should be for development to become an ethos in public 
management and governance by which every public official operates and executes his or her duties.

The COE must address the issue of what the exact duties are of the ward councillor, the PR councillor and ward committee members. The perception is often that representatives do not have a clue as to what they are supposed to do. Ward committees' main function with the assistance of councillors and municipal officials is to influence policy through public participation by identifying and prioritising communities' developmental needs. This also requires that the mayor and his executive committee members assist councillors in addressing their issues that they bring to council.

Addressing this superordinate of democratic and accountable government, councillors, ward committee members and officials are to be made aware of the fact that all actors are to be included in addressing community needs and that no voice albeit the weakest or the poorest is to be drowned out by more influential, powerful, better organised and wellconnected groups. The COE will have to educate its officials and public representatives that they have to be careful of groups that often claim to speak on behalf of the poor and vulnerable but only have their own interests at heart. This requires the design of specific and explicit strategies to uplift women, children or young people to emancipate them.

Communities must also be educated to hold their public representatives to account by devising social accountability tools, although politicians will never accede to it, but it is for them to know that they are accountable for the promises they make to the electorate. An example of a social accountability tool can be a scorecard of how many meetings the councillor or the ward committee conducted. Another example can be an evaluation about what has been decided on and what actions were taken. Other examples include an assessment about whether promises were kept and how long has it taken for a project to be completed and whether it has been completed within budget and on time. The scorecard is a culmination of an agreement of the ward councillor and his committee in which they said that they can be held to it in terms of their performance.

All actors in the IDP, budget and other municipal processes must take ownership for these processes in order for it to be innovative and flexible in dealing with communities' needs. This will allow processes to be sustainable and effective because the community will even support a decision that goes against themselves, for example, where they perhaps have to pay more for a service; however, the importance thereof is that they were part of the decision-making process.

It is inherently good if the public participates in local government matters as envisaged by the constitution. However, the effectiveness of the process depends on how councillors, officials and the community view these processes.
Are they inclusive, democratic and is there equity in the process while deliberating issues? For processes to be effective, citizens must get feedback regarding their inputs that they gave. This means that inputs cannot just be symbolic, it must be a two-way communication because participation must elicit reaction or a response from the municipality. Effective public participation always involves the element of advocacy where advocacy is always on behalf of a community, never of an individual. Citizens are thus the eyes and ears of the COE because the city wants to know what citizens and communities are thinking about the services it renders. This also requires from the city to indicate that they act upon communities' inputs.

This study emphasised that a democratic and accountable government must ensure that it provides communities with sustainable services and that the lack of these services not only impacts communities economically and/or socially, but also psychologically to such an extent that people even question their own existence, humanity, identity and selfworth. This is the first study of its sort that looked at the micro-level impact of poor or non-accountable democratic governance. Possible future research that could flow from this study is a cross-sectional study within the next few years, perhaps with the same participants, to see whether and how their lived experiences have improved or not. Another study that could flow from here is, determining whether the capacitation of councillors, ward committee members and even municipal officials has taken place. It can also find out how this capacitation influenced and affected the lives and lived experiences of communities within the city and whether they feel that they have made an impact on the municipal processes, and whether they perceive that they own these processes.

\section{Acknowledgements}

This article is based on an unpublished thesis submitted to the University of Johannesburg by Jerome J. Patience in 2021 titled: 'Variables influencing participatory budgeting in the City of Ekurhuleni' Available here: https://ujcontent.uj.ac. $\mathrm{za} /$ vital/access/services/Download/uj:44124/SOURCE1? view=true, under the supervision of Prof. D. Nel-Sanders and Prof. C.J. Auriacombe.

\section{Competing interests}

The authors declare that they have no financial or personal relationships that may have inappropriately influenced them in writing this article.

\section{Authors' contributions}

J.J.P. as the doctoral student was the main contributor, data collector and author while D.N.-S. served as supervisor.

\section{Funding information}

This research received no specific grant from any funding agency in the public, commercial or not-for-profit sectors. 


\section{Data availability}

The data that support the findings of this study are available from the corresponding author, J.J.P., upon reasonable request.

\section{Disclaimer}

The views and opinions expressed in this article are those of the authors and do not necessarily reflect the official policy or position of any affiliated agency of the authors, and the publisher.

\section{References}

Alase, A., 2017, 'The interpretative phenomenological analysis (IPA): A guide to a good qualitative research approach', International Journal of Education \& Literacy Studies 5(2), 9-19. https://doi.org/10.7575/aiac.ijels.v.5n.2p.9

Asatryan, Z. \& De Witte, K., 2015, 'Director democracy and local government efficiency', European Journal of Political Economy 39, 58-66. https://doi. org/10.1016/j.ejpoleco.2015.04.005

Auriacombe, C.J. \& Van der Walt, G., 2016, UJ Internal handbook: Democratising service delivery for programme code PMG 2A11, Section B, University of Johannesburg, Johannesburg.

Bernhardt, Y., 2016, UJ Internal handbook: Public policy management for programme code PMG 3A11, University of Johannesburg, Johannesburg.

Bratu, S., 2010, 'Fundamental values of political discourse in a democratic society', Contemporary Readings in Law and Social Justice 2(2), 301-306.

Chernick, I., 2016, 'Residents desperate for some attention', The Star, 15 June, p. 4.

Creighton, R.A., 2005, The public participation handbook, Josey-Bass, San Francisco, CA.

Creswell, J.W., 2014, Research design: Qualitative, quantitative and mixed methods approaches, 4th edn., SAGE Publications, London.

Diedericks, M. \& Seitlholo, S., 2018, 'Challenges facing the effective functioning of ward committees as a mechanism to promote local democracy in the former Tlokwe local municipality', Politeia 37(1), 1-17. https://doi.org/10.25159/0256$8845 / 4287$

Gberevbie, D.E., 2014, 'Democracy, democratic institutions and good governance in Nigeria', Eastern Africa Social Science Research Review 30(1), 133-152. https:// doi.org/10.1353/eas.2014.0005

Goldsmith, S., 2008, 'Governing by network producing public value with private actors', State Summit on Innovative Transportation Funding and Financing, June 24, 2008, NGA Center for Best Practices.

Esau, M., 2007, Deepening democracy through local participation, Project: Policy management, governance and poverty alleviation in the Western Cape, Page Art, Cape Town.

Flanagan, L., 2016, '67 750 protests on community issues over 17 years', The Star, 15 June, p. 4.

Institute of Directors South Africa (IODSA), 2016, King IV report on corporate governance for South Africa, Institute of Directors South Africa, Johannesburg.

Klijn, E. \& Koppenjan, J., 2016, Governance network in the public sector, viewed 18 January 2021, from https://www.researchgate.net/publication/284158898 Governance_Networks_in_the_Public_Sector.

Kroukamp, H., 2016, 'Strategies to restore confidence in South African local government', African Journal of Public Affairs 9(3), 105-116.

Larkin, M. \& Thompson, A.R., 2011, Interpretative phenomenological analysis in mental health and psychotherapy research, John Wiley \& Sons, London.

Laverty, S.A., 2003, 'Hermeneutic phenomenology and phenomenology: A comparison of historical and methodological considerations', International Journal of Qualitative Methods. International Institute for Qualitative Methodology (IIQM) 2(3), 21-35. https://doi.org/10.1177/160940690300200303

MacDermott, A.F.N., 2002, 'Living with angina pectoris - A phenomenological study', European Journal of Cardiovascular Nursing 1(4), 265-272. https://doi. org/10.1016/S1474-5151(02)00047-6

Madonsela, T., 2017, Interview on drive time with Bongani Bingwa on Talk Radio 702 7 December, viewed 11 December 2017, from http://www.702.co.za/ articles/283815/the-democracy-festival\#.

Masango, R., 2001, 'Public participation in policy-making and implementation with specific reference to the Port Elizabeth Municipality', Unpublished doctor of administration thesis, University of South Africa, Pretoria.

Mashaba, H., 2016, 'Active citizenry is the only way to bring change', City Press, 29 May, p. 5
National Planning Commission (NPC), 2011, National development plan (NDP) 2030 our future - Make it work, The Presidency, Republic of South Africa, Pretoria.

Overstrand Municipality, 2016, Draft public participation policy, March, Overstrand Municipality, Hermanus.

Patience, J.J., 2015, 'Infrastructure management challenges in Ekurhuleni Metropolitan Municipality', Unpublished master's thesis, University of Johannesburg, Johannesburg.

Patience, J.J., 2021, 'Variables influencing participatory budgeting in the City of Ekurhuleni', Unpublished doctoral thesis, University of Johannesburg, Johannesburg.

Pietkiewicz, I. \& Smith, J.A., 2012, 'A practical guide to using interpretative phenomenological analysis in qualitative research psychology', Psychological Journal 18(2), 361-369.

Piper, L. \& Deacon, R., 2008, Partisan ward committees, elite accountability and community participation: The Msunduzi case, viewed 18 October 2018, from https://www.researchgate.net/publication/242732012_Partisan_ward committees_elite_accountability_and_community_participation_the_ Msunduzi_case.

Razaki, K.A. \& Lindberg, D.L., 2012, 'Municipal budgeting: Positives, pitfalls and politics', ASBBS Annual Conference: Las Vegas, 19(1), 775-786.

Reiners, G.M., 2012, 'Understanding the differences between Husserl's (descriptive) and Heidegger's (interpretive) phenomenological research', Nursing \& Care 5(1), 1-3. https://doi.org/10.4172/2167-1168.1000119

Schermbrucker, N., 2020, We won't fix development until we fix our municipalities, viewed 28 September 2020, from https://www.dailymaverick.co.za/article/202007-30-we-wont-fix-development-until-we-fix-our-municipalities/.

Sebugwawo, M., 2016, 'Advancing participatory democracy \& development in South Africa: Towards a new strategy of governance', viewed 13 April 2016, from http:// www afesis org za/local-governance/local-governance-articles/143-advancingparticipatory-democracy-development-in-south-africa-towards-a-new-strategyof-governance.html.

Shaidi, W., Pillay, P., Raga, K. \& Taylor, J.D., 2011, 'An overview of the link between ward committees, development and community participation with reference to the Nelson Mandela Bay Municipality', Administratio Publica $19(2), 115-128$

Shinebourne, P., 2011, The theoretical underpinnings of interpretative phenomenological analysis, viewed 04 June 2017, from http://www. biomedsearch.com/article/theoretical-underpinnings-InterpretativePhenomenological-Analysis/288874145.html.

Smith, J.A., 2004, 'Reflecting on the development of interpretative phenomenological analysis and its contribution to qualitative research in psychology', Qualitative Research in Psychology 1(1), 39-54.

Smith, J.A., Flowers, P. \& Larkin, M., 2009, Interpretative phenomenological analysis: Theory, method and research, SAGE Publications, Thousand Oaks, CA.

Smith, T. \& De Visser, J., 2009, Are ward committees working? Insights from six case studies, Community Law Centre (University of the Western Cape), Cape Town.

Sørensen, E. \& Torfling, J., 2004, Making governance networks democratic, Roskilde Universitet, Roskilde.

South Africa (Republic), 1996, Constitution of the Republic of South Africa, Act no. 108 of 1996, Government Printers, Pretoria.

South Africa (Republic), 1997, The white paper on transforming public service delivery (Batho Pele), Government Printers, Pretoria.

South Africa (Republic), 1998, The white paper on local government, Government Printers, Pretoria.

South Africa (Republic), 1998, Local government: Municipal structures act, Act no. 117 of 1998, Government Printers, Pretoria.

South Africa (Republic), 2000, Local government: Municipal systems act, Act no. 32 of 2000, Government Printers, Pretoria.

South Africa (Republic), 2003, Local government: Municipal finance management act, Act no. 56 of 2003, Government Printers, Pretoria.

South Africa (Republic), 2004, Local government: Municipal property rates act, Act no. 6 of 2004, Government Printers, Pretoria.

South African Local Government Information Centre (SALGIC), 2018, Community protests monitor, The SA Local Government Briefing, September (9), 36-39.

South African Cities Network (SACN), 2016, South African cities report 2016, SACN Johannesburg.

Torfling, J. \& Sørensen, E., 2014, 'The European debate on governance networks: Towards a new and viable paradigm', Policy and Society 33(4), 329-344. https:// doi.org/10.1016/j.polsoc.2014.10.003

Waugh, W.L. \& Waugh, W.W., 2004, 'Phenomenology and public administration', International Journal of Organization Theory and Behaviour 6(4), 405-431. https://doi.org/10.1108/IJOTB-07-03-2004-B006

Wilikilagi, V., 2009, 'What is network governance and its implications for public policy formulation?', October 23, 2009. https://doi.org/10.2139/ssrn.1494757 